\title{
Understanding by Design (UbD) in EFL Teaching: The Investigation of Students' Foreign Language Learning Motivation and Views ${ }^{1}$
}

\author{
Nihal Yurtseven ${ }^{1}$, Sertel Altun ${ }^{2}$ \\ ${ }^{1}$ School of Foreign Languages, Yildiz Technical University, Istanbul, Turkey \\ ${ }^{2}$ Faculty of Education, Yildiz Technical University, Istanbul, Turkey \\ Correspondence: Nihal Yurtseven, School of Foreign Languages, Yildiz Technical University, 34210, Istanbul, Turkey
}

Received: November 19, 2015 Accepted: December 4, 2015 Online Published: December 14, 2015

doi:10.11114/jets.v4i3.1204

URL: http://dx.doi.org/10.11114/jets.v4i3.1204

\begin{abstract}
In today's world, where learning a foreign language is highly prioritized, it is an important prerequisite that education has components that are lasting, meaningful, and transferable to everyday life. Moreover, these components would have a positive influence on student motivation. The purpose of this study is to investigate students' language learning motivation and views about integration of Understanding by Design (UbD) into their lessons. The study was carried out through mixed method research. For the quantitative part, pre-test post-test experimental design was carried out while action research was instrumented for the qualitative part of the study. 10 teachers and 436 students participated the study. Of the 436 students, 225 were in the treatment group and 211 were in the control group. Through the action research, 10 instructors who were trained about $\mathrm{UbD}$, were divided into four groups, each of which designed three different unit plans and implemented them in their classes. As quantitative data collection tool, Motivation/Attitude Scale (MAS), which was developed by Dörnyei and adapted to Turkish by Mendi (2009) was used. For the qualitative data of the study, focus group interviews were held with 10 students. The quantitative data was analyzed through the analysis of covariance and independent samples t-test. The qualitative data was analyzed through content analysis. The quantitative results of the study indicated that there was a significant difference in A and B level students' foreign language learning motivation in favor of the treatment group. The qualitative findings indicated that UbD implementation had a positive impact on students' foreign language learning motivation and knowledge transfer skills. These findings underline the importance of foreign language motivation and providing students with experiential learning.
\end{abstract}

Keywords: understanding by design, EFL, motivation, curriculum, design

\section{Introduction}

It has become vital to know a foreign language, especially English in the 21st century, in which the borders have lost their significance and international relations have been intensified. The increase in the awareness of knowing English has caused most countries to implement a wide variety of practices to equip their citizens with this skill. In today's world, where learning a foreign language is highly prioritized, it is an important prerequisite that education has components that are lasting, meaningful, and transferable to everyday life. Moreover, these components would have a positive influence on student motivation.

Although there has been a vision about teaching English in Turkey for many years, it faces certain difficulties because of a set of instructional problems from time to time. Among these instructional problems are:

- Content transfer has become an objective rather than a tool (Wiggins \& McTighe, 2011),

- Language is not accepted as a communication tool and grammar rules are passively transferred during the lessons (Gomleksiz, 2011),

- Current EFL programs are far from the principle of learning by exploring, questioning, and understanding (Ersoz, 2014),

- The nature and conditions of EFL teaching are not sufficiently understood by authorities (Bayraktaroglu, 2012).

\footnotetext{
1 This study is part of a doctoral dissertation.
} 
The way how these instructional problems are handled and precautions are taken is of crucial importance and in recent years, there has been a tendency to engage teachers with lesson design in order to eliminate such kind of problems (Wallace \& Loughran, 2012; Craig, 2012). There are different ways to occupy teachers with designing units or elaborating on their lesson plans.

Understanding by Design (UbD) can bring a breath of fresh air to EFL teaching by directly authorizing teachers about unit design and by functioning differently with each of its components. The focus of EFL teaching is to set a foundation for students to develop their language learning skills with the content presented (Wiggins \& McTighe, 2007). The problem of content transfer becoming an objective rather than a tool can be handled with UbD's essential assumption of making the knowledge meaningful and spreading the authentic and original usage of target language in classes (Wiggins \& McTighe, 2011). In addition, UbD stresses that it is important/crucial not to restrict EFL teaching to practices such as memorizing the alphabet, learning grammar rules and technical knowledge or word-for-word translation. It also prioritizes the communicational aspect of the language (Wiggins \& McTighe, 2005; Wiggins \& McTighe, 2011). Apart from these, it emphasizes the importance of transferring the knowledge into new learning situations and using the skill of speaking in different learning environments by acquiring the language in a meaningful and explorative way (Wiggins $\&$ McTighe, 2007). By highlighting the communicative aspect of language instruction, UbD triggers the creative usage of the newly learned language on different occasions.

$\mathrm{UbD}$ is based on the consideration of minimizing incidental learning or learning by inborn capacity through regarding all learners and their preferences by giving teachers the role of the designer (Wiggins \& McTighe, 1998). UbD is dominated by "backward design" approach. In this approach, teachers determine which evidences they want to reach before they plan what they teach and how (Wiggins \& McTighe, 2005). Backward design consists of three stages, namely desired results, evidence and learning plan (Wiggins \& McTighe, 2011). At the stage of desired results, the objectives of the unit are illuminated within the framework of transfer, meaning, and acquisition by referring to the terms of big idea and essential questions (Wiggins \& McTighe, 2011). At the stage of evidence, teachers determine the evidence that they would like to see and they decide how to reveal them through performance tasks. They utilize the performance task criteria, abbreviated as GRASPS at this stage (Wiggins \& McTighe, 2005). At the last stage, named as learning plan, teachers determine what to teach, how and in what order. For the organization of these, they benefit from WHERETO principles, which help to make the instruction more effective (Wiggins \& McTighe, 2005; Wiggins, McTighe, 2011). With these basic assumptions, UbD aims to provide a practical design process for teachers and lasting learning experience for students.

For students, numerous variables have an impact on their learning process. Especially in EFL learning and teaching, motivation is among the most important criteria and objectives for the success (Gardner, 2006). Foreign language learning motivation has an important share in the language learning process and it helps to determine to what extent the student assumes a positive, active and engaging role (Oxford \& Shearin, 1994). As the motivation has a key role in some aspects, the classroom practices should increase students' motivation in the short-term and student achievement in the long-term. The importance of foreign language motivation has been investigated in various studies (Cho, 2013; Karakis, 2014; Lee, 2012; Mendi, 2009; Meyer, 2013; Pak, 2014; Pineda, 2011; Su, 2012; Swanson, 2013; Ushida, 2003; Yurtseven, 2010; Yurtseven et al., 2014) and it has been concluded that motivation is an important parameter in the success of EFL teaching. In addition,

This study is of crucial importance as it investigates what contributions the implementation of UbD had on students' foreign language learning motivation within the framework of an experiment and action plan. The scarcity of studies about teaching a foreign language by using the communicative aspect or producing alternatives to traditional course book coverage at preparatory classes at universities in Turkey increases the relevance of this study. The purpose of this study is to investigate students' foreign language learning motivation and views about UbD-integrated lessons. The research questions are:

1. Is there a significant difference between instrumental motivation post-test scores in favor of the treatment group according to the levels of the students?

2. Is there a significant difference between integrative motivation post-test scores in favor of the treatment group according to the levels of the students?

3. What are the views of students about UbD implementation?

\section{Method}

\subsection{Research Design}

The research was carried out via mixed method design. Mixed method is used when both qualitative and quantitative components exist in a study (Creswell, 2012). For the quantitative part, pre-test post-test experimental design was used 
while action research was instrumented for the qualitative part of the study. In pre-test post-test experimental design, the researcher identifies treatment and control groups, administers the pre-test to both groups, conducts the experiment with the treatment group only, and then administers the post-test to both groups again (Creswell, 2012; Karasar, 2007). Action research is a kind of research used to identify an educational problem, develop a solution, and follow it systematically throughout the process. In addition, educational practices are shaped and improved with the help of emerging data in these researches (Creswell, 2012; Burns, 2010; Berg, 2001).

\subsection{Participants}

The research was carried out during the spring semester of 2014-2015 academic year, with 10 instructors and 436 students, 225 of whom were the treatment group and 211 of whom were the control group attending the School of Foreign Languages preparation classes at Yildiz Technical University. The students attended three different levels; A level, B level, and C level. A level students were the students starting preparation class with the highest placement scores while B level students had medium-level scores and C level students had the lowest placement scores. The information related to the students are given in Table 1.

Table 1. Student Participants

\begin{tabular}{ccccccc}
\hline \multirow{2}{*}{ Level } & \multicolumn{2}{c}{ Treatment } & \multicolumn{2}{c}{ Control } & \multicolumn{3}{c}{ Total } \\
\cline { 2 - 7 } & $\mathrm{N}$ & $\%$ & $\mathrm{~N}$ & $\%$ & $\mathrm{~N}$ & $\%$ \\
$\mathrm{~A}$ & 44 & 51.16 & 42 & 48.84 & 86 & 100 \\
$\mathrm{~B}$ & 115 & 50.43 & 113 & 49.57 & 228 & 100 \\
$\mathrm{C}$ & 66 & 54.09 & 56 & 45.91 & 122 & 100 \\
Total & 225 & 51.60 & 211 & 48.40 & 436 & 100 \\
\hline
\end{tabular}

\subsection{Data Collection Instruments}

As a quantitative data collection instrument, Motivation/Attitude Scale (MAS), which was developed by Dornyei (1998) and adapted to Turkish by Mendi (2009), was used. MAS is a scale having two sub-dimensions, namely instrumental motivation and integrative motivation. It is a five-level Likert scale consisting of 30 items. Instrumental motivation is defined as students' positive attitude towards the language they learn and the community in which that language is spoken. Integrative motivation is a kind of positive attitude and a sense of belongingness the individual has towards the language and the community in which that language is spoken. On the other hand, instrumental motivation appears when the learners perceive the language only as an instrument and they learn it when it is for their sake (Gardner, 2006).

For the validity of MAS, the factor analysis was instrumented. After the factor analysis, it was found out that the scale had two factors as in the original form and had a cumulative factor loading of $48 \%$. For the reliability of the scale, Cronbach's Alpha coefficients were checked. For the integrative motivation sub-dimension, the Cronbach's Alpha coefficient was .92 while it was .89 for the instrumental motivation sub-dimension, which meant that the scale was reliable.

Focus group interview constitutes the qualitative data of the study. Focus group interview is a meeting in which individuals with common characteristics or experiences are brought together in order to obtain their perceptions about a predetermined topic at a moderate and non-threatening atmosphere (Yildirim \& Simsek, 2008; Yin, 2011). Within the scope of the present study, focus group interviews were carried out in order to find out student views about UbD implementation. Two focus group interviews were conducted with the same group a week after the other and the students were asked the same questions. During the interviews, what contributions UbD implementations had on students' motivation and students' views were examined.

For the validity and reliability of qualitative data collection instrument, Lincoln and Guba's (1985) credibility, transferability, dependability and confirmability terms were referred to. Initially, the transcript forms were created for the collected qualitative data. Three experts and focus group interview participants confirmed the accuracy of the forms. Besides, focus group interviews were repeated twice, to check whether the participants' answers were the same as the questions asked. In addition, three different experts examined the transcripts carefully to reach at codes, categories, and themes. Although some discrepancies occurred, experts and the researcher came together and reached a consensus about the last form of categories and themes. After the consensus, the participants also confirmed those codes, categories, and themes.

\subsection{Action Plan}

The action plan began with the identification of the problem. Students' lack of foreign language learning motivation was the starting point for the action plan. The teachers' observations in the first semester and the students' MAS scores influenced the identification of the study and UbD was seen as a convenient solution to the problem. The teachers were primarily trained about UbD. After the training, teachers formed four design groups. Two groups made unit plans for Reading course and two groups made unit plans for Listening \& Speaking course. Each group designed three unit plans 
throughout the semester and they implemented their plans in their classes. They designed unit plans by sticking to current curriculum's objectives and enriching the content via UbD's guiding principles (e.g. big idea, essential questions, performance tasks, enduring understanding, differentiation, methodological diversity etc.). They made designs for upcoming units and they shared their experiences at the evaluation meetings after each implementation. The action plan was reshaped with the help of views gathered at the meetings and the teachers proceeded to the following design. Thereby, each group designed three unit plans for Reading and Listening \& Speaking courses in total and they implemented their designs.

\subsection{Data Analysis}

The quantitative data of the study were analyzed via the analysis of covariance and independent samples t-test in order to find out whether foreign language learning motivation of treatment and control groups were significant. The qualitative data of the study were analyzed via content analysis. Content analysis is carried out in order to define data, uncover facts within them and form patterns (Yildirim \& Simsek, 2008; Glesne, 2012). In the present study, the data obtained from focus group interviews were transcribed and analyzed via content analysis. In addition, three different experts examined the transcriptions in order to reach codes, categories, and themes. At first, different findings were obtained about categorizing codes and reaching themes. For instance, there were fun, visuality, and interest categories under motivation theme at first. However, when the codes were reexamined in accordance with experts' views, it was concluded that it would be more accurate to name visuality category as attractiveness and interest category as clarity. The participants also confirmed the codes, categories, and themes reached.

\section{Findings}

\subsection{Quantitative Data Findings}

\subsubsection{A Level}

To answer the first and second research questions for A level, analyses were conducted by examining the assumptions required for the analysis of covariance through Levene's Test and Test for Equality of Regression. At the end of the test, it was concluded that the assumptions could not be met and analysis of covariance could not be carried out. Therefore, independent samples t-test was carried out in order to find out whether the difference between accessed scores (between pre-test and post-test scores) was significant. The descriptive statistics of integrative and instrumental motivation accessed scores are given in Table 2.

Table 2. The descriptive statistics of integrative and instrumental motivation accessed scores for A level

\begin{tabular}{llllll}
\hline GROUP & & $\mathrm{N}$ & $\mathrm{M}$ & $\mathrm{SD}$ & $\mathrm{SED}$ \\
\hline Integrative Motivation & Treatment & 44 & 11.77 & 15.09 & 2.27 \\
\cline { 2 - 6 } & Control & 42 & -2.54 & 14.78 & 2.28 \\
\hline Instrumental Motivation & Treatment & 44 & 4.13 & 6.71 & 1.01 \\
\cline { 2 - 6 } & Control & 42 & -.61 & 11.63 & 1.79 \\
\hline
\end{tabular}

When Table 1 is examined, it is seen that the treatment group, which consisted of 44 students, had an average integrative motivation of 11.77. Its standard deviation value was 15.09 , and standard error difference was 2.27 . The control group, which consisted of 42 students, had an average of -2.54 . Its standard deviation value was 14.78 , and standard error difference was 2.28. The treatment group had an average instrumental motivation of 4.13. Its standard deviation value was 6.71, and standard error difference was 1.01. The control group had an average instrumental motivation of -.61. Its standard deviation value was 11.63, and standard error difference was 1.79. As can be understood, there is a difference between the scores of treatment and control group. Independent Samples $t$-Test was instrumented to find out whether this difference was significant or not. The findings about independent samples t-test can be found in Table 3 .

Table 3. Integrative and instrumental motivation independent samples t-test for A level

\begin{tabular}{llllccc}
\hline Variables & Mean Difference & Standard Error Difference & $\mathrm{df}$ & $\mathrm{t}$ & $\mathrm{p}$ & $\mathrm{d}$ \\
\hline Integrative Motivation & 14.32 & 3.22 & 84 & .44 & .00 & .95 \\
\hline Instrumental Motivation & 4.75 & 2.03 & 84 & 2.33 & .02 & .50 \\
\hline
\end{tabular}

When Table 3 is examined, it can be seen that there is a significant difference in integrative and instrumental motivation levels of treatment and control groups at $p<0.05$ level $(p=.00<.05 ; p=.02<.05)$. This means that the integrative and instrumental motivation is significant in favor of the treatment group. On the other hand, when $\mathrm{d}$ value, which was calculated via Cohen's d formula, is examined, it is seen that the effect size of integrative motivation is .95. This value indicates that it has a high level of effect size. At the instrumental motivation column, it is seen that the effect size is .50, 
which means that it has a moderate effect size (Cohen, 1998).

\subsubsection{B Level}

To answer the first and second research questions for B level, analyses were conducted by examining the assumptions required for the analysis of covariance through Levene's Test and Test for Equality of Regression. At the end of the test it was concluded that the assumptions were met and analysis of covariance could be carried out for integrative motivation, whereas the assumptions were not met for instrumental motivation. The analysis of covariance was carried out for integrative motivation. On the other hand, independent samples t-test was carried out for instrumental motivation in order to find out whether the difference between accessed scores (between pre-test and post-test scores) was significant. The descriptive statistics of integrative motivation scores are given in Table 4.

Table 4. The descriptive statistics of integrative motivation scores for B level

\begin{tabular}{cccccc}
\hline \multirow{2}{*}{ Groups } & \multirow{2}{*}{$\mathrm{N}$} & \multicolumn{3}{c}{ Pre-Test } & \multicolumn{2}{c}{ Post-Test } \\
\cline { 3 - 6 } & 115 & $\mathrm{M}$ & $\mathrm{SD}$ & $\mathrm{M}$ & $\mathrm{SD}$ \\
\hline Treatment & 113 & 72.96 & 14.35 & 73.55 & 13.44 \\
\hline Control & 113 & 13.51 & 72.10 & 14.10 \\
\hline
\end{tabular}

When Table 4 is examined, it is seen that the treatment group, which consisted of 115 students, had an average pre-test integrative motivation of 68.96 and its standard deviation value was 14.35. As post-test, it had average of 73.55 and 13.44 standard deviation value. The control group, which consisted of 113 students, had an average pre-test integrative motivation of 72.28 and its standard deviation value was 13.51. Its post-test average was 72.10 and standard deviation value was 14.10. To analyze whether the difference is significant, independent samples t-test was carried out. The results of the independent samples t-test can be found in Table 5 .

Table 5. Integrative motivation independent samples t-test for B level

\begin{tabular}{lllllll}
\hline Variable & $\begin{array}{l}\text { Mean } \\
\text { Difference }\end{array}$ & $\begin{array}{l}\text { Standard Error } \\
\text { Difference }\end{array}$ & $\mathrm{df}$ & $\mathrm{t}$ & $\mathrm{p}$ & $\mathrm{d}$ \\
\hline $\begin{array}{l}\text { Integrative } \\
\text { Motivation }\end{array}$ & 3.67 & .89 & 226 & 4.10 & .00 & .54
\end{tabular}

When Table 5 is examined, it can be seen that there is a significant difference in integrative motivation levels of treatment and control groups at $\mathrm{p}<0.05$ level $(\mathrm{p}=.00<.05)$. This means that the integrative motivation is significant in favor of the treatment group. In addition, when d value, which was calculated via Cohen's d formula, is examined, it is seen that the effect size of integrative motivation is .54. This value indicates that it has a moderate level of effect size (Cohen, 1998).

The descriptive statistics of accessed instrumental motivation accessed scores are given in Table 6 .

Table 6. The descriptive statistics of accessed instrumental motivation scores for B level

\begin{tabular}{llllll}
\hline & GROUP & $\mathrm{N}$ & $\mathrm{M}$ & $\mathrm{SD}$ & SED \\
\hline \multirow{2}{*}{$\begin{array}{l}\text { Instrumental } \\
\text { Motivation }\end{array}$} & Treatment & 115 & 2.20 & 5.28 & .49 \\
\cline { 2 - 6 } & Control & 113 & -1.46 & 7.99 & .75 \\
\hline
\end{tabular}

When Table 6 is examined, it is seen that the treatment group, which consisted of 115 students, had an average accessed integrative motivation score of 2.20. Its standard deviation value was 5.28, and standard error difference was .49. The control group, which consisted of 113 students, had an average accessed score of -1.46 . Its standard deviation value was 7.99, and standard error difference was .75 Whether the significance is different was analyzed through the analysis of covariance. The results of the analysis of covariance for instrumental motivation can be seen in Table 7:

Table 7. Analysis of covariance on instrumental motivation post-test scores for B level

\begin{tabular}{cccccc}
\hline & Sum of Squares & Df & Mean Square & F & $p$ \\
\hline Contrast & 660.40 & 1 & 660.40 & 5.40 & .02 \\
\hline Error & 27375.16 & 224 & 122.21 & & \\
\hline
\end{tabular}

When Table 7 is examined, the results of the analysis of covariance indicate that there is a significant difference between post-test scores in favor of the treatment group when instrumental motivation pre-test scores of treatment and control groups are taken under control.

\subsubsection{Level}

To answer the first and second research questions for $\mathrm{C}$ level, analyses were conducted by examining the assumptions required for the analysis of covariance via Levene's Test and Test for Equality of Regression. At the end of the tests it was concluded that the assumptions could not be met and analysis of covariance could not be carried out. Therefore, independent samples t-test was carried out in order to find out whether the difference between accessed scores (between pre-test and post-test scores) was significant. The descriptive statistics of integrative and instrumental motivation 
accessed scores are given in Table 8.

Table 8. The descriptive statistics of integrative and instrumental motivation accessed scores for $\mathrm{C}$ level

\begin{tabular}{llllll}
\hline GROUP & & $\mathrm{N}$ & $\mathrm{M}$ & $\mathrm{SD}$ & $\mathrm{SED}$ \\
\hline Integrative & Treatment & 66 & 2.15 & 7.04 & .86 \\
\cline { 2 - 6 } Motivation & Control & 56 & -.48 & 13.45 & 1.79 \\
\hline Instrumental & Treatment & 66 & 1.21 & 5.49 & .67 \\
\cline { 2 - 6 } Motivation & Control & 56 & -1.58 & 10.75 & 1.43 \\
\hline
\end{tabular}

When Table 8 is examined, it is seen that the treatment group, which consisted of 66 students, had an average integrative motivation of 2.15. Its standard deviation value was 7.04, and standard error difference was .86. The control group, which consisted of 56 students, had an average of -.48. Its standard deviation value was 13.45, and standard error difference was 1.79. The treatment group had an average instrumental motivation of 1.21. Its standard deviation value was 5.49, and standard error difference was .67. The control group had an average instrumental motivation of -1.58 . Its standard deviation value was 10.75 , and standard error difference was 1.43 . Independent Samples $t$-Test was instrumented to find out whether there is a significant difference or not. The findings about independent samples t-test can be found in Table 9 .

Table 9. Integrative and instrumental motivation independent samples t-test for $\mathrm{C}$ level

\begin{tabular}{lcccccc}
\hline Variables & Mean Difference & Standard Error Difference & $\mathrm{df}$ & $\mathrm{t}$ & $\mathrm{p}$ & $\mathrm{d}$ \\
\hline Integrative Motivation & 2.63 & 1.90 & 120 & 1.38 & .16 & .24 \\
\hline Instrumental Motivation & 2.80 & 1.51 & 120 & 1.85 & .06 & .32 \\
\hline
\end{tabular}

When Table 9 is examined, it can be seen that there is not a significant difference in integrative and instrumental motivation levels of treatment and control groups at $p<0.05$ level $(p=.16>.05 ; p=.06>.05)$. This means that the integrative and instrumental motivation is not significant in favor of the treatment group. On the other hand, when $\mathrm{d}$ value, which was calculated via Cohen's $d$ formula, is examined, it is seen that the effect size of integrative motivation is .24. This value indicates that it has a low level of effect size. At the instrumental motivation column, it is seen that the effect size is .32, which also means that effect size is low (Cohen, 1998).

\subsection{Qualitative Data Findings}

For the third research question, the content analysis was carried out to analyze the data obtained from focus group interviews. The identified themes, categories, some sample codes and sample quotations about the content analysis can be found in Table 10.

Table 10. Content analysis findings

\begin{tabular}{|c|c|c|c|}
\hline Theme & Category & Sample Codes & Sample Data \\
\hline \multirow[t]{3}{*}{ Motivation } & Fun & $\begin{array}{l}\text { Comedy } \\
\text { Differentness } \\
\text { Performance task } \\
\text { Song } \\
\end{array}$ & \multirow{3}{*}{$\begin{array}{l}\text { "Even the most uninterested student participated in } \\
\text { the lesson with these implementations. Normally, I } \\
\text { get bored after } 15 \text { minutes. Bu these implementations } \\
\text { were effective for me because of their visual } \\
\text { aspects". (S3, Female, 18). } \\
\text { "Although I don't usually take part in lessons, even } \\
\text { I told my ideas during performance tasks. Six hats } \\
\text { technique was effective and it increased my } \\
\text { participation". (S5, Male, 20). } \\
\text { "These implementations made a big change in me. } \\
\text { My motivation has increased so much that I'm even } \\
\text { thinking of learning another language". (S2, Female, } \\
\text { 19). }\end{array}$} \\
\hline & Attractiveness & $\begin{array}{l}\text { Presentation } \\
\text { Posters } \\
\text { Big idea } \\
\text { Robot } \\
\text { Six hats } \\
\text { Participation }\end{array}$ & \\
\hline & Clarity & $\begin{array}{l}\text { Big idea } \\
\text { Slides } \\
\text { Topics } \\
\text { Teachers' being active } \\
\text { Learning capacity } \\
\text { Videos }\end{array}$ & \\
\hline \multirow[t]{2}{*}{$\begin{array}{l}\text { Knowledge } \\
\text { Transfer }\end{array}$} & Real Life & $\begin{array}{l}\text { Business life } \\
\text { Video games } \\
\text { Current issues }\end{array}$ & \multirow{2}{*}{$\begin{array}{l}\text { "I didn't feel ashamed of speaking English. Because } \\
\text { there were worse students than me. Without caring } \\
\text { about how I speak, I expressed myself comfortably } \\
\text { during the implementations". (S1, Female, 18). } \\
\text { "We watched real video games samples during the } \\
\text { implementations. It was something unusual for us. } \\
\text { Most of us researched those videos after the class". } \\
\text { (S8, Male, 19). } \\
\text { "UbD taught us to regard life with a big idea. I may } \\
\text { also use essential questions and big ideas in the future, } \\
\text { when I'm describing something to my colleagues in my } \\
\text { business life". (S7, Male, 19). }\end{array}$} \\
\hline & Speaking & $\begin{array}{lll}\text { Increase } & \text { in } & \text { teachers' } \\
\text { speaking English } & \\
\text { Increase in } & \text { English } \\
\text { speaking } & \\
\text { Efforts for } & \text { speaking } \\
\text { English } & & \\
\text { Courage } & & \\
\text { Self-confidence } & \end{array}$ & \\
\hline
\end{tabular}

As can be seen in Table 10, two main themes emerged when the data gathered from focus group interview were analyzed. These themes are motivation and knowledge transfer. When the motivation theme is examined, it can be 
concluded that the theme is made up of three categories, namely fun, attractiveness, and clarity. Students stated that covering units in a different way, having fun elements during the lessons, carrying out performance tasks and songs were enjoyable and they added that having fun in the lessons increased their motivation.

This semester students are worried whether they are going to pass or fail. However, it is good to have fun when you are studying. It really caught my attention. Even the people who hated studying were trying to do something, trying to write something. They started thinking about how to tell it in a funnier way. (S1, Female, 18).

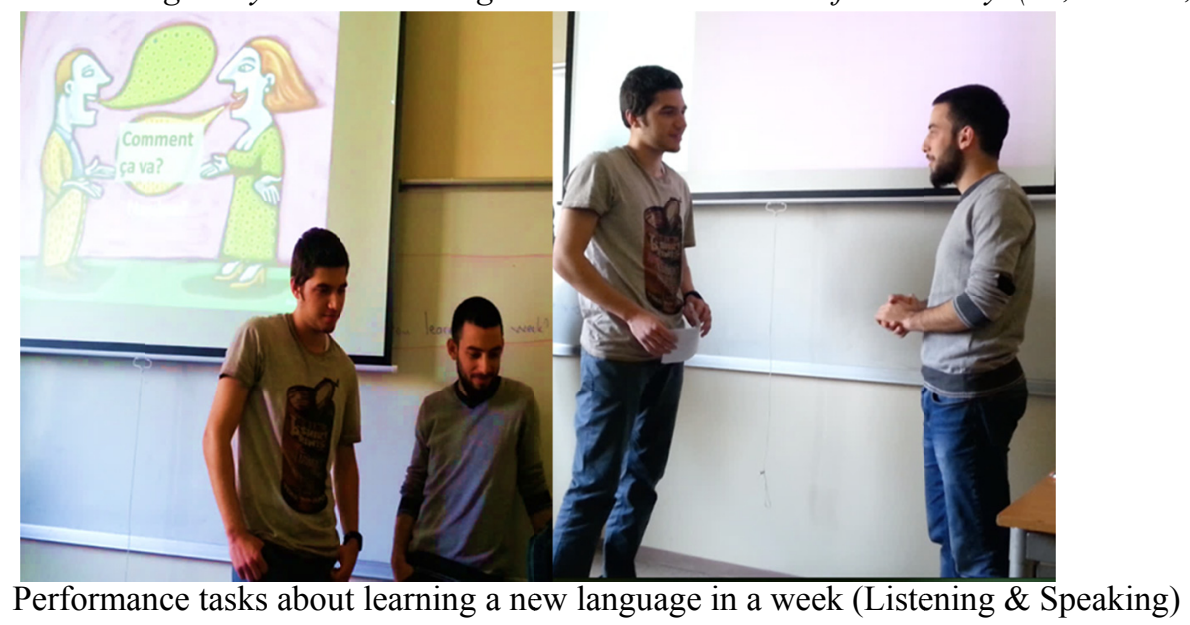

When the attractiveness category was examined, it is seen that codes such as presentation, posters, big idea, robot, six hats were the components that integrated a visual aspect to the lessons. Students' statements revealed that the increase in the attractiveness of the lesson influenced their motivation positively.

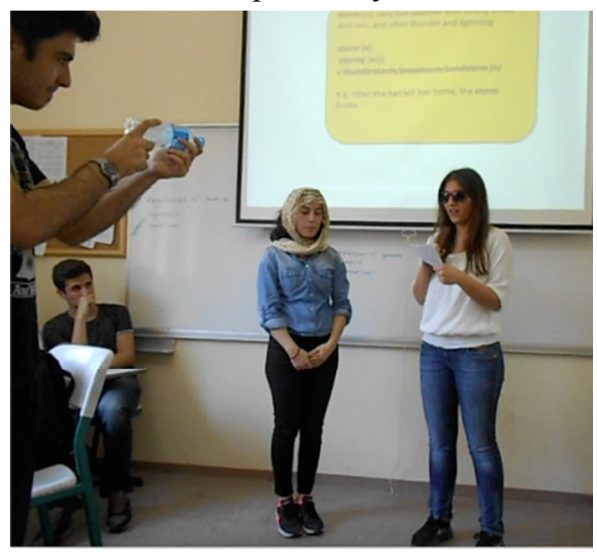

Performance tasks about being the victims of a disaster (Reading)

These implementations aroused my interest in the lesson. Instead of doing something on my cell phone, I listened to the teacher. She was telling interesting things. I mean, she was talking about video games or so...I was really intrigued. (S7, Male, 19).

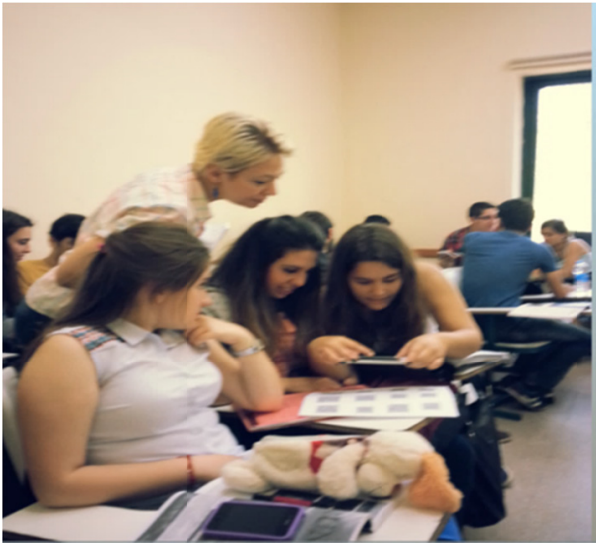

QR coding (Reading / Warm-up) 
Clarity is another category that emerged after the analyses. Students pointed out that the slides, the videos, the big ideas, and the topics chosen facilitated their understanding. They also added that teachers became more active during these implementations, which, in turn, increased their motivation, too.

What we are trying to learn is not a subject, but a language. Before doing anything, we should start by maximizing teacher-student interaction. I believe those activities were useful as we used many visual materials. They were encouraging for us. Besides, the teacher was properly organized and those all minimized our getting bored. (S8, Male, 19).

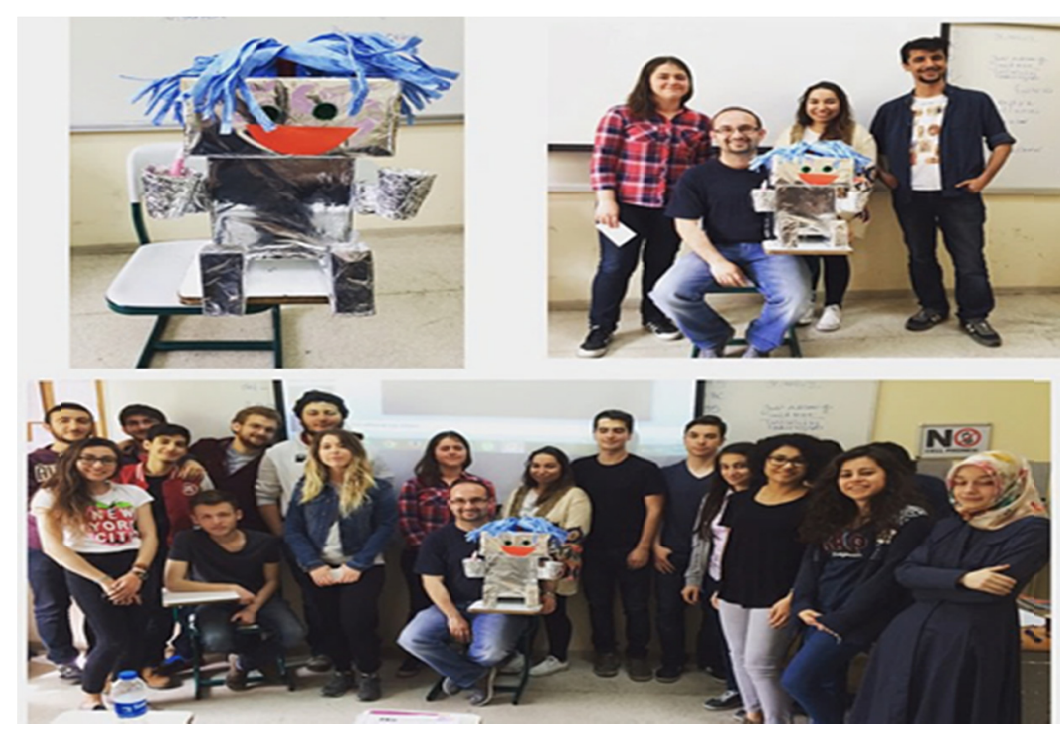

Performance task about designing a robot teacher (Listening \& Speaking)

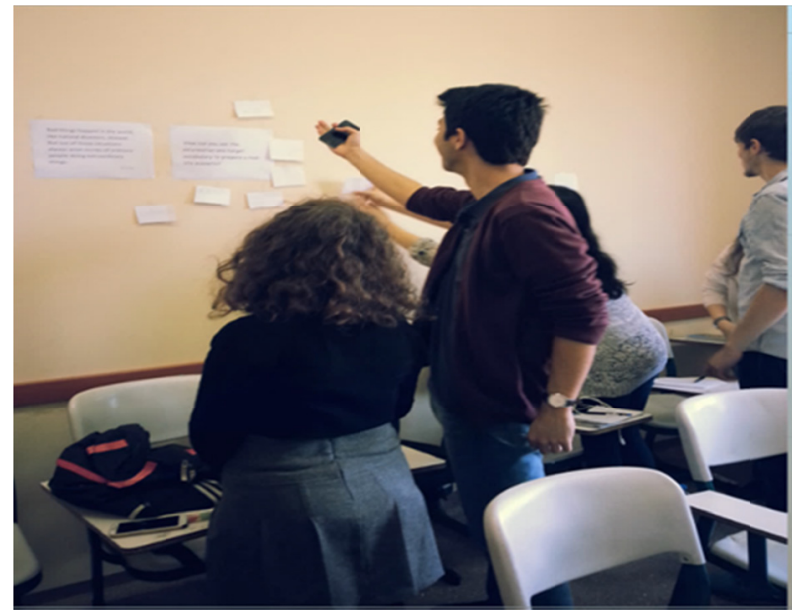

Post-it study about essential questions at the end of the unit

Another theme emerged after the analysis is knowledge transfer. Under this theme, there are two main categories, namely real life and speaking. When the real life category is examined, it was concluded that students found UbD implementations related to real life, UbD lessons' topics were all up to date and slices of life. Students also pointed out that they could use the knowledge they gained from the lessons in their business life.

One day, if, I need to learn something about my profession, I would like to learn it in this way. Let us suppose that I needed to learn Russian or French for my profession. Why do not I learn in this way? Because I learned that I cannot learn a language by memorizing grammar rules for 10 years. At least I know what I should not do! (S10, Male, 20).

Students also emphasized that UbD lessons prioritized the speaking skill more than the other skills. The reason for this might be teachers' practicing more English, students' making more effort to speak English and the increase in students' courage and self-confidence about speaking English. 
Now I am more self-confident. I could not speak English in front of anyone. However, I had to do it because it was obligatory in those lessons. It was important both for me and for the teacher. Therefore, you need to be well prepared. You go to the front and tell about yourself. (S3, Female, 18).

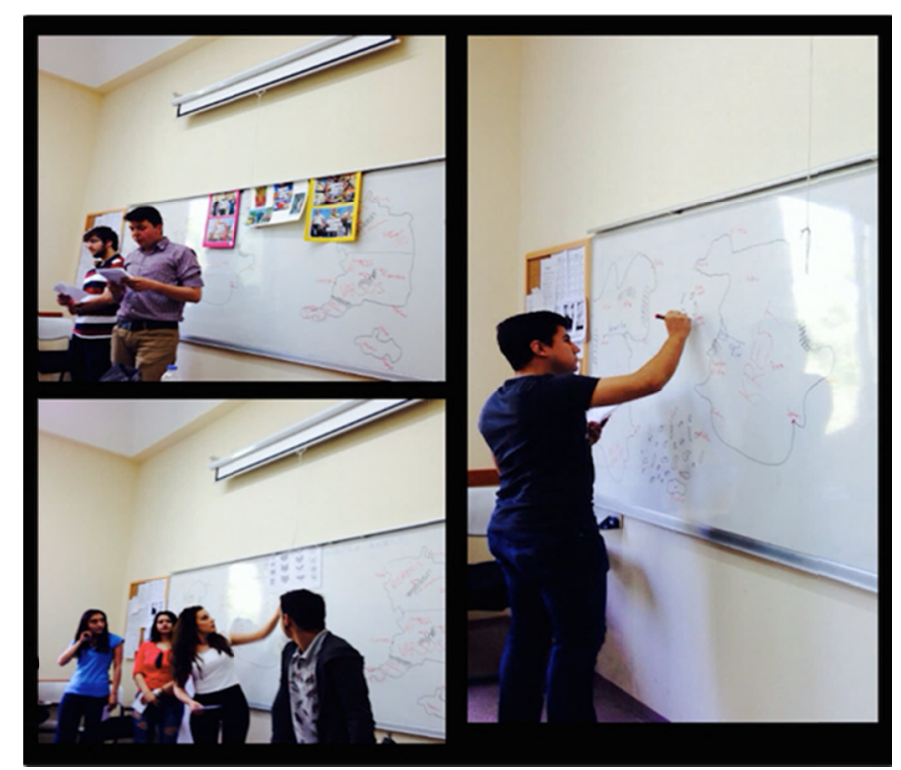

Six hats thinking debate study (Listening \& Speaking)

\section{Discussion}

The findings revealed that UbD implementation had a positive influence on A and B level students' foreign language learning motivation. Compared to the control group, the accessed scores of the treatment group is significantly different in favor of the treatment group, which indicates that UbD implementation increased those students' foreign language learning motivation. Wiggins and McTighe $(2011 ; 2005)$ stated that making sense of the knowledge is critical in foreign language learning. From this point of view, the integration of $\mathrm{UbD}$ in EFL teaching requires deep internalization of the authentic and original use of the language rather than word-for-word translation or text analysis. The present study provided opportunity for going beyond the traditional course book coverage through the UbD implementations, which had a positive influence on students' motivation. The reason for this is that UbD lessons helped students experience the authentic and original use of English and this aroused the students' interest in the lesson. Another reason is that the UbD implementations enriched the lessons as they included many visual aspects and fun elements. Finally yet importantly, performance tasks such as learning a new language within a week, designing a robot teacher, interviewing a professional in English and many others allowed the students to expand their horizons and develop their speaking skills. The reason why there was no significant difference between the motivation scores of $\mathrm{C}$ level students can be that $\mathrm{C}$ level students were the students with lowest English language background and knowledge. That's why it might have been challenging for them to take part in tasks which required them to transfer their skills and knowledge into new learning situations or to use the language authentically. As Yurtseven et al. (2014) stated, the achievement and motivational factors have a predictive power on each other and it can be difficult for students with low achievement to have a high level of foreign language learning motivation.

The literature also presents studies with similar results. Swanson (2013) aimed at investigating students' foreign language motivation and perception in her study and concluded that diversity in educational activities increased student motivation. Boztepe (2013) conducted a study in order to identify the effect of using audio-visual materials on second language (L2) students' motivation and achievement. The findings of the study indicated that using audio-visual material influenced students' L2 motivation and achievement in a positive way. Lee (2012) examined the relationship between L2 motivation and task engagement in his study and concluded that even students with low L2 motivation were eager to participate on condition that the tasks given were suitable for their field of interest. Carreira (2011) also concluded that it was an important parameter for students to learn English in an enjoyable atmosphere. The more fun elements the English class contains, the higher motivation the students will have. Nikolov (1999) carried out a study in order to learn the views of Hungarian students aged 6-14 about why they learned a foreign language and what kind of classroom activities they liked. At the end of the study it was concluded that the variables that provided intrinsic motivation most were activity, task, materials, and exercises.

The objective in learning English or any other world language is to communicate in the target language in different 
situations effectively (Wiggins \& McTighe, 2011). Within this framework, knowledge transfer is an important criterion to determine whether the instruction met its objectives (Wiggins \& McTighe, 2007). When the findings were examined in this framework, it was noteworthy that the theme knowledge transfer was directly related to real life. Because, a large number of students expressed that the knowledge they acquired during the implementation of UbD was something that could be used in their real life, and even in their business life. As Yurtseven et al. (2013) pointed out, the integration of $\mathrm{UbD}$ into classroom settings provides an environment for interaction, active participation, and making use of the knowledge gained within authentic situations.

As stated above, transfer is an important skill that refers to enduring understanding. The most fundamental transfer skill in foreign language learning is being able to communicate in a complex and real environment successfully with a good accent and speed that is understandable to everyone who does not know the speaker's native language (Wiggins \& McTighe, 2007). Relating to the subject, the students stated that the implementations of UbD had many activities that aimed to improve students' speaking skill, which made them feel anxious at first. Later on, these activities helped them to gain courage and confidence about speaking English. Because, as Yurtseven et al. (2015) stated, being in an enriched educational setting with its content, materials and visuality has a crucial importance for increasing students' foreign language learning environment.

There are similar studies in the literature. Corvo (2014) aimed at examining UbD-based teaching practices and found out that UbD and similar frameworks are effective tools in determining and concretizing contents of lessons. Similarly, Molina (2013) aimed at raising the awareness of curriculum planning and investigating the effect of this practice on the students' academic achievement. At the end of the study, it was concluded that UbD could be an effective tool to raise students' academic achievement. In another study, Anderson (2012) aimed at determining the effect of UbD-based reading circles and found out that UbD had a positive impact on the students' attitudes of the reading course. Schoellhorn (2012) aimed at integrating UbD in history teaching and examine the effect of it on student learning. At the end of the study it was concluded that this kind of a practice encouraged students to search and discover. Tacaks (2010), aimed at examining the effect of UbD-based formative lesson plan on the students' mathematics achievement and found out that UbD-based lessons contributed to the students' lasting and meaningful learning. Stotter (2004) examined the effect of introducing a two-week instructional unit in agriculture and biotechnology lesson at a technology high school and found out that the implementation increased the level of understanding in the sample group.

Learning a foreign language is affected by the presence of a wide range of variables and motivation is the leading one. In this regard, it is of crucial importance that any activity that will be used in the learning environment should have qualities that will increase student motivation. In addition, knowledge transfer is directly related to integrating an experiential content into EFL lessons and it is highly estimated in foreign language teaching. It is very important that students can transfer what they come across in a EFL learning atmosphere into their daily lives and that they are not obliged to memorize academic rules and information. Only in this way can they learn a foreign language in a meaningful and lasting way.

In the light of the findings and the result of the study, the following suggestions can be made for future studies:

1. For the professional aspect, the contribution of UbD to the teachers' professional development can be researched.

2. For the institutional aspect, UbD's effect on school culture can be researched. Small UbD groups can be created and the products can be discussed in bigger groups.

3. For the students' aspect, a longitudinal study can be carried out. The participants' grades in Vocational English lessons can be examined at undergraduate level.

4. This study was carried out at a university's preparatory classes for Reading and Listening \& Speaking courses. Future studies can be carried out for different subject areas in EFL teaching.

5. The present study revealed that UbD had significant contributions to the speaking skill. Future studies can focus more on the aspect of authentic usage of a foreign language.

6. Future studies can be carried out within a wider period and population.

\section{References}

Anderson, A. R. (2012). Implementing literature circles: An experimental study in an English language learners' classroom. (Unpublished Doctoral Dissertation). Capella University, USA.

Bayraktaroglu, S. (2012). Yabanci Dil Egitimi Gercegi, Yabanci Dille Egitim Yanilgisi. Turkiye'de Yabanci Dil Egitiminde Egilim Ne Olmali? 1. Yabanci Dil Egitimi Calistayi Bildirileri, 12-13. November 2012.

Berg, B. L. (2001). Qualitative research methods for the social sciences. USA: Allyn \& Bacon. 
Boztepe, C. (2013). The effect of using audio-visual materials on foreign language learners' levels of motivation and achievement. (Unpublished Master's Thesis). Ondokuzmayis University, Turkey.

Burns, A. (2010). Doing action research in English language teaching: A guide for practitioners. USA: Routledge.

Carreira, J. M. (2012). Motivational orientations and psychological needs in EFL learning among elementary school students in Japan. System: An International Journal of Educational Technology and Applied Linguistics, 40(2), 191-202. http://dx.doi.org/10.1016/j.system.2012.02.001

Cho, Y. G. (2013). Second language motivation, the L2 self and English as an international language: A sociolinguistic investigation of Korean English leaners' discourses in texts and contexts. (Unpublished Doctoral Dissertation). The State University of New York, USA.

Cohen, J. (1998). Quantitative methods in psychology. Psychological Bulletin, 112(1), 155-159. http://dx.doi.org/10.1037/0033-2909.112.1.155

Corvo, A. F. (2014). Utilizing the national research council's (NRC) conceptual framework for the next generation science standards (NGSS): A self-study in my science, engineering, and mathematics classroom. (Unpublished Doctoral Dissertation). Columbia University, USA.

Craig, C. (2012). Professional development through a teacher-as-curriculum-maker lens. In M. Kooy \& K. V. Veen (Eds). Teacher learning that matters (pp.22-43). USA: Routledge:.

Creswell, J. W. (2012). Educational research: Planning, conducting, and evaluating quantitative and qualitative research. USA: Pearson Education, Inc.

Dornyei, Z. (1998). Motivation in second and foreign language learning. Language Teaching, 31(3), 117-135. http://dx.doi.org/10.1017/S026144480001315X

Ersoz, A. (2014). Ingilizce: Ders Degil, Iletisim Araci. http://www.aljazeera.com.tr/gorus/ingilizce-ders-degil-iletisim-araci

Gardner, R. C. (2006). The socio-educational model of second language acquisition: A research paradigm. EUROSLA Yearbook, 6(1), 237-260. http://dx.doi.org/10.1075/eurosla.6.14gar

Glesne, C. (2012). Nitel arastirmaya giris. (A. Ersoy \& P. Yalcinoglu, Trans). Turkey: Anı Yayincilik.

Gomleksiz, M. N., \& Elaldi, S. (2011). Yapilandirmaci Yaklasim Baglaminda Yabanci Dil Ogretimi. Turkish Studies, 6 (2), 443-454.

Karakis, O. (2014). Lise ogrencilerinin Ingilizce dersine yonelik kaygilari, motivasyonlari, oz-yeterlik algilari ve Ingilizce ders basarilari arasındaki iliski. (Unpublished Doctoral Dissertation). Abant Izzet Baysal University, Turkey.

Lee, H. (2012). ESL learners' motivation and task management in technology enhanced language learning contexts. (Doctoral Dissertation). Washington State University.

Lincoln, Y. S., \& Guba E. G. (1985). Naturalistic Inquiry. USA: Sage Publications.

Mendi, H. B. (2009). The relationship between reading strategies, motivation and reading test performnce in foreign language learning. (Unpublished Master's Thesis). Marmara University, Turkey.

Meyer, C. L. (2006). Learning to teach conceptually: Four preservice teachers' journeys. (Unpublished Doctoral Dissertation). University at Albany, USA.

Molina, W. (2013). Teachers' views of backwards planning in a suburban elementary shool in Hawaii. (Unpublished Doctoral Dissertation). Walden University, USA.

Nikolov, M. (1999). 'Why do you learn English?' 'Because the teacher is short.' A study of Hungarian children's foreign language learning motivation. Language Teaching Research, 3(1), 33-56.

Noble, C. (2011). How does understanding by design influence student achievement in eight grade social studies? (Unpublished Doctoral Dissertation). Capella University, USA.

Oxford, R., \& Shearin J. (1994). Language learning motivation: Expanding the theoretical framework. The Modern Language Journal, 78(1), 12-28. http://dx.doi.org/10.1111/j.1540-4781.1994.tb02011.x

Pak, C. (2014). Speak up or be silent? Language learners' anxiety and motivation on speaking up in ELL and non-ELL classrooms. (Unpublished Doctoral Dissertation). University of Washington, USA.

Pineda, A. S. (2011). Attitude, motivation, and English language learning in a Mexican college context. (Unpublished Doctoral Dissertation). The University of Arizona, USA. 
Schoellhorn, L. (2012). "Bringing history to life" Exploring the historic cemetery as a primary classroom resource. (Unpublished Master's Thesis). Webster University, USA.

Stotter, D. E. (2004). Assessment of the learning and attitude modification of technology education students who complete an instructional unit on agriculture and biotechnology. (Unpublished Doctoral Dissertation). North Carolina State University, USA.

Swanson, K. A. (2013).Teacher perceptions of technology and learner motivation in the second language classroom. (Unpublished Doctoral Dissertation). Capella University, USA.

Tacaks, J. A. (2010). Using formative assessment in professional learning communities to advance teaching and learning. (Unpublished Doctoral Dissertation). Walden University, USA.

Ushida, E. (2003). The role of students' attitudes and motivation in second language learning in online language courses. (Unpublished Doctoral Dissertation). Carnegie Mellon University, USA.

Wallace, J., \& Loughran, J. (2012). Science teacher learning. In F. K. Tobin, \& C. J. McRobbie (Eds.), Second international handbook of science education (spp. 295-306). USA: Springer. http://dx.doi.org/10.1007/978-1-4020-9041-7_21

Wen, J. Q. (2009). Stimulating foreign language learning motivation-from the perspective of cognition and meta-cognition. US-China Foreign Language, 7(10), 34-38.

Wiggins, G., \& McTighe, J. (1998). Understanding by design. USA: Association for Supervision and Curriculum Development.

Wiggins, G., \& McTighe, J. (2005). Understanding by design. USA: Association for Supervision and Curriculum Development.

Wiggins, G., \& McTighe, J. (2007). Schooling by design: Mission, action, and achievement. USA: Association for Supervision and Curriculum Development.

Wiggins, G., \& McTighe, J. (2011). The understanding by design guide to creating high-quality units. USA: Association for Supervision and Curriculum Development.

Yildirim, A., \& Simsek, H. (2008). Sosyal bilimlerde nitel arastirma yontemleri. Turkey: Seckin Yayincilik.

Yurtseven, N. (2010). Mentorluk hizmetinin Yabanci Diller Yuksekokulu'nda okuyan ogrencilerin akademik basarilari, oz-yeterlik algilari ve kaynaklari yonetme stratejileri uzerindeki etkisi. (Unpublished Master's Thesis). Yildiz Technical University, Turkey.

Yurtseven, N., Alci, B., \& Karatas, H. (2014). Factors affecting academic performance in EFL context: A modeling study. The International Journal of Research in Teacher Education, 5(1), 13-23.

Yurtseven, N., Altun, S., \& Aydin, H. (2015). An analysis on motivational beliefs of preparatory class students about learning English. The International Journal of Educational Researches, 6(1), 13-30.

Yurtseven, N., Dogan, S., \& Altun, S. (2013). Planning differentiated science instruction using understanding by design: The case of Turkey. Siirt Universitesi Sosyal Bilimler Enstitüsü Dergisi, 1(1), 1-20.

\section{$(\mathrm{cc}) \mathrm{Br}$}

This work is licensed under a Creative Commons Attribution 3.0 License. 